\title{
Six Pack
}

National Cancer Institute

\section{Source}

National Cancer Institute. Six Pack. NCI Thesaurus. Code C78778.

A product containing six individual units. 